\title{
MENINGKATKAN KEMAMPUAN KELINCAHAN PEMAIN UKM SEPAKBOLA UNIVERSITAS WAHID HASYIM MELALUI LATIHAN LADDER DRILL
} TAHUN 2017

\author{
YUDHI PURNAMA ${ }^{\mathbf{1}^{*}}$, MUHLISIN ${ }^{2}$ \\ ${ }^{1}$ Jurusan Pendidikan Jasmani Kesehatan Rekreasi, FKIP, Universitas Wahid Hasyim \\ ${ }^{2}$ Jurusan Pendidikan Jasmani Kesehatan Rekreasi, FKIP, Universitas Wahid Hasyim \\ *email: purnama1725@gmail.com
}

\begin{abstract}
Proper practice method is an important element in improving the ability of agility, among others, using ladder drill tool or stair ladder. Rapid foot reaction becomes one form of physical exercise that works to train foot agility and coordination in a balanced manner. The purpose of this research is to know how big influence of ledder drill training to the agility of football player player from Unwahas. This study uses the design of One Group PretestPosttest Design research, with a population of players Football Unwahas SMEs, as many as 40 players. The sample used in this research is 28 people, data analysis of research done by comparing data of pretest and posttest result after treatment using one sample t-test. The results obtained that the average agility time of pretest result is 16.73 seconds, with the highest time of 21.6 seconds and the lowest time 14.6 seconds. While at the post test, the average agility time is 15.76 seconds, the highest time is 19.2 seconds and the lowest time is 14.2 seconds. Ho is rejected and $\mathrm{Ha}$ is accepted because sig $=0,000<0,05$, it means difference of difference is different so it can be said effective ladder drill treatment to increase the result of agility. The result of research is sig $=0.000<0,05$, it means difference of difference is different so it can be said effective ladder drill treatment to increase the result of agility, so it can be concluded that there is influence between ladder drill training to ability agility.
\end{abstract}

Keywords: influence, ladder drill, agility, ukm football

\section{PENDAHULUAN}

Sepakbola merupakan salah satu cabang olahraga permainan yang paling banyak digemari oleh sebagian besar manusia yang ada di bumi ini. Demikian juga di Indonesia bahkan mendapat simpati di hati masyarakat. Sepakbola digemari oleh semua lapisan masyarakat baik dari tingkat daerah, nasional, dan internasional, dari usia anak-anak, dewasa hingga orang tua, mereka senang memainkan sendiri atau sebagai penonton. Dewasa ini permainan sepakbola tidak sekedar dilakukan untuk tujuan rekreasi dan pengisi waktu luang akan tetapi dituntut suatu prestasi yang optimal. Prestasi yang tinggi hanya dapat dicapai dengan latihan-latihan yang direncanakan dengan sistematis dan 
dilakukan secara terus-menerus, dengan demikian peran dari seorang pelatih sangat penting untuk mengawasi dan memberikan metode latihan yang tepat.

Pencapaian prestasi puncak dapat diraih bila pembinaan atlet melalui tahapan tingkat pemula sampai atlet berprestasi atau dari tahap usia dini sampai tahap usia dewasa. Pembinaan sepakbola usia dini atau usia muda mengharuskan para pelatih, guru penjas atau pembina olahraga sepakbola memperhatikan secara cermat dan teliti dalam memberikan bimbingan kepada para siswa atau altetnya. Oleh karena itu, pelatih, guru penjas atau pembina olahraga sepak bola harus memahami karakteristik siswa atau atletnya sesuai tingkat usianya. Untuk memperoleh prestasi yang baik dalam permainan sepakbola tentu saja harus didukung oleh penguasaan teknik dasar sepakbola. Dalam rangka usaha untuk meningkatkan prestasi maksimal pada cabang olahraga yang ditekuni, seorang atlet perlu sekali memperhatikan faktor-faktor penentunya. Faktor-faktor penentu dapat disebutkan ada tiga faktor penting yaitu : 1) kondisi fisik atau tingkat kesegaran jasmani, 2) ketepatan teknik atau ketrampilan yang dimiliki, dan 3) masalah-masalah lingkungan.

Kondisi fisik adalah salah satu unsur pendukung yang sangat penting untuk menunjang performa di lapangan. Kondisi fisik akan mempengaruhi permainan secara signifikan. Komponen-komponen kondisi fisik yang harus dikuasai oleh pemain sepakbola menurut Timmo Scheunemann (2010:14) antara lain adalah : 1) Speed, 2) strength, 3) Endurance, 4) Felxibility, 5) Accuration, 6) Power, 7) Coordination, 8) Reaction, 9) Balance, dan 10) Ability. Dari sepuluh komponen kondisi fisik tersebut, kelincahan merupakan kemampuan biomotor dari unsur-unsur kemampuan fisik secara umum, yaitu kemampuan untuk mengubah arah gerakan tubuh atau bagian tubuh secara (Djoko Pekik Irianto, 2009 : 68). Sedangkan koordinasi adalah kemampuan untuk melakukan gerakan dengan berbagai tingkat kesukaran dengan cepat dan tepat secara efisien (Djoko Pekik Irianto, 2009 : 68). Kelincahan dan koordinasi dapat ditingkatkan melalui latihan ledder drill. Untuk berlatih gerak ini dibutuhkan alat yang menyerupai anak tangga yang diletakkan pada bidang datar/lantai dan 
beberapa penanda (titik) yang diatur dengan jarak kurang dari 2 meter.

Unit Kegiatan Mahasiswa Sepakbola Unwahas peneliti jadikan obyek penelitian karena semakin banyaknya kejuaraan sepakbola antar perguruan tinggi, baik negeri/swasta, tingkat regional ataupun nasional serta event-event daerah di Jawa Tengah. Disamping itu, UKM sepakbola Unwahas memiliki anggota yang cukup besar, karena pemain tidak hanya dari prodi pendidikan jasmani akan tetapi anggota UKM terdiri dari semua fakultas yang ada di Unwahas. Ditambah lagi dengan hasil pengamatan pada setiap latihan, banyak pemain yang masih tidak efektif dalam melakukan teknik dasar. Kondisi tersebut dapat dipengaruhi oleh kelincahan dan koordinasi yang tidak baik dari pemain. Ditambah lagi dengan metode pelatih yang memberikan latihan secara monoton sehingga para pemain mengalami kebosanan dalam melakukan latihan.
Seorang pelatih harus memilih metode latihan yang tepat, yang akan digunakan dalam meningkatkan kelincahan. Salah satunya adalah menggunakan alat ladder drill atau tangga hketangkasan. Reaksi kaki yang cepat dapat menjadi salah satu bentuk latihan fisik yang berfungsi melatih kelincahan kaki.

\section{METODOLOGI}

2.1. Design Penelitian

Penelitian ini menggunakan desain penelitian One Group Pretest-Posttest Design, agar dapat diketahui lebih akurat, sebelum dan sesudah diberi perlakuan (Sugiyono, 2001: 64). Penelitian ini akan membandingkan hasil pretest dan posttest kelincahan dan koordinasi pemain sepakbola UKM Unwahas tahun 2017.

Untuk memperjelas proses penelitian yang akan dilaksanakan, maka desain penelitiannya sebagai berikut:

\section{Pre-test}

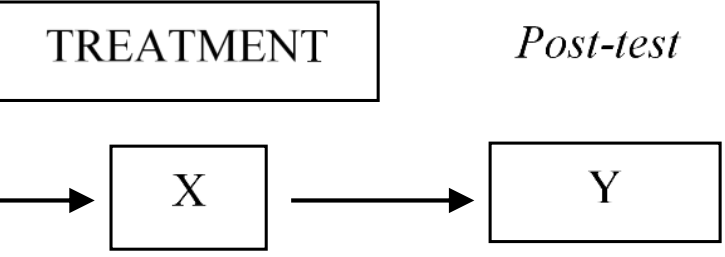

Gambar 2.1 Desain Penelitian 
Keterangan :

$$
\begin{aligned}
& \text { X : Variabel Bebas (Ledder Drill) } \\
& \text { Y:Variabel Terikat (Tes Kelincahan) }
\end{aligned}
$$

\subsection{Instrumen Penelitian}

Instrumen penelitian yang digunakan untuk mengumpulkan data dalam penelitian ini adalah tes. Untuk mengukur kelincahan menggunakan shuttle run test yang dikemukakan Brian Mackenzie dalam bukunya 101 Perfomance Evaluation Tests (2005: $57)$.

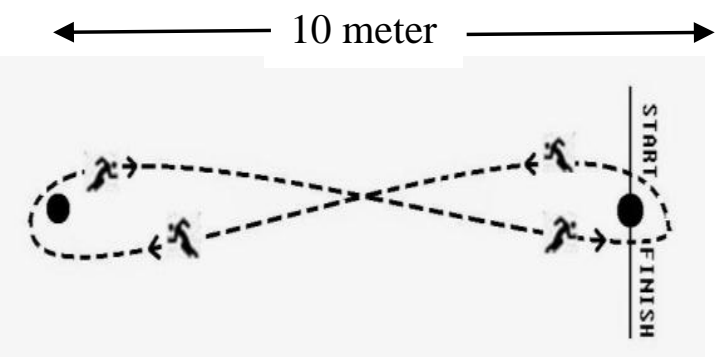

Gambar 2.2 Shuttle Run Test

(Sumber: Brian Mackenzie, 2005: 57)

Keterangan :

- - - :Jalur Berlari
— : Garis Start dan Finish
: Titik atau Point yang harus dilewati/diputari

Table 2.1 Penilaian Shuttle Run Test

\begin{tabular}{|c|c|}
\hline Skor & Waktu (detik) \\
\hline 5 & $<15,5$ \\
\hline 4 & $16-15,6$ \\
\hline 3 & $16,6-16,1$ \\
\hline 2 & $17,1-17,6$ \\
\hline 1 & $17,7-17,2$ \\
\hline
\end{tabular}

Teknik pengumpulan data dalam penelitian ini menggunakan tes dan pengukuran. Metode latihan ladder drill dilakukan secara bervariasi.

\subsection{Teknik Analisis Data}

Penelitian ini menggunakan metode eksperimen. Analisis data penelitian dilakukan dengan membandingkan data hasil pretest dan posttest setelah perlakuan. Apabila nilai t hitung lebih lebih kecil dari nilai $\mathrm{t}$ tabel maka Ho (hipotesis nol) diterima dan jika nilai t hitung lebih besar dari nilai t tabel maka Ho ditolak.

$$
\text { Rumus yang digunakan uji-t }
$$
adalah:

$$
t=\frac{\bar{t}-H_{\theta}}{\mathrm{s} / \sqrt{n}} \quad \begin{aligned}
& \mathrm{t}=\text { nilai t hitung } \\
& \bar{x}=\text { rata-rata sample } \\
& \mu_{0}=\text { nilai parameter } \\
& s=\text { standar deviasi sample } \\
& n=\text { jumlah sample }
\end{aligned}
$$

Hipotesis Deskriptif penelitian yang akan di uji adalah sebagai berikut:

Ho : Tidak ada pengaruh yang signifikan latihan ladder drill terhadap kelincahan pemain UKM Sepakbola Unwahas $\mathrm{Ha}$ : Ada pengaruh yang signifikan latihan ladder drill terhadap kelincahan pemain UKM Sepakbola Unwahas 


\section{HASIL DAN PEMBAHASAN}

Penelitian dilaksanakan

selama 3 Bulan berlokasi di kampus Universitas Wahid Hasyim Semarang yaitu mulai bulan September s.d November 2017. Penelitian Eksperimen dilakukan dari pengambilan data Pre Test dilanjutkan pelaksanaan Treatment pada sampel dan Post Test. Penelitian dilakukan kepada sampel peserta UKM Sepakbola Universitas Wahid Hasyim Semarang sebanyak 28 pemain.

\subsection{Hasil Penelitian}

Tabel 3.1 Hasil Pre Test Kelincahan

\begin{tabular}{|c|l|c|c|}
\hline No & Keterangan & Jumlah & Prosentase \\
\hline 1 & Sempurna & 9 & $32.1 \%$ \\
\hline 2 & Baik Sekali & 4 & $14.3 \%$ \\
\hline 3 & Bai k & 4 & $14.3 \%$ \\
\hline 4 & Cukup & 1 & $3.6 \%$ \\
\hline 5 & Kurang & 10 & $35.7 \%$ \\
\hline
\end{tabular}

Tabel 3.2 Hasil Post Test Kelincahan

\begin{tabular}{|c|l|c|c|}
\hline No & Keterangan & Jumlah & Prosentase \\
\hline 1 & Sempurna & 16 & $32.1 \%$ \\
\hline 2 & Baik Sekali & 4 & $14.3 \%$ \\
\hline 3 & Baik & 3 & $14.3 \%$ \\
\hline 4 & Cukup & 2 & $3.6 \%$ \\
\hline 5 & Kurang & 3 & $35.7 \%$ \\
\hline
\end{tabular}

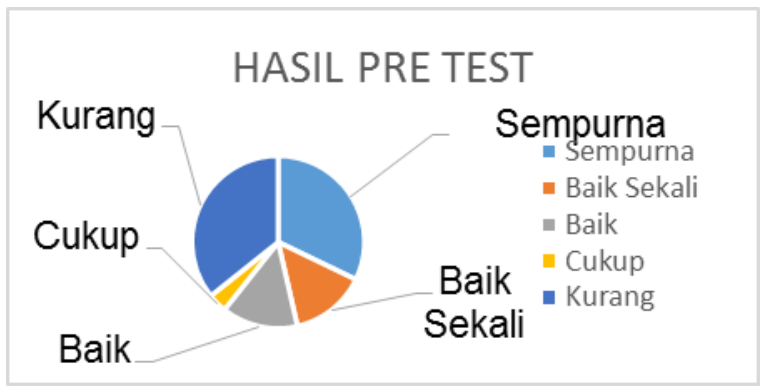

Gambar 3.1 Diagram Hasil Pre Test

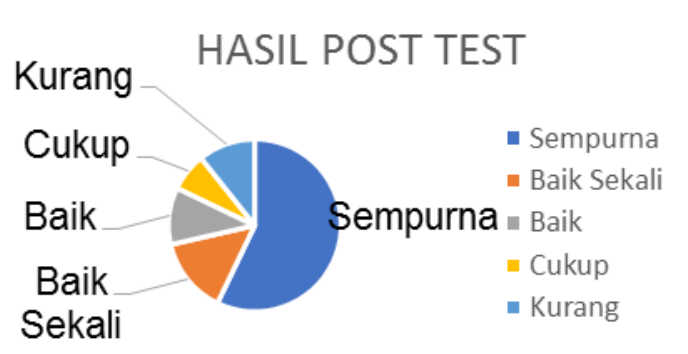

Gambar 3.2 Diagram Hasil Post test

3.2. Hasil Pengaruh Latihan Ladder Drill terhadap Hasil Kelincahan

Paired Samples Statistics

\begin{tabular}{|ll|c|r|r|r|}
\hline & & Mean & $N$ & Std. Deviation & $\begin{array}{c}\text { Std. Error } \\
\text { Mean }\end{array}$ \\
\hline Pair 1 & SEBELUM & 16.7357 & 28 & 1.76409 & .33338 \\
& SESUDAH & 15.7643 & 28 & 1.30731 & .24706 \\
\hline
\end{tabular}

Setelah dilakukan treatment terlihat ada peningkatan waktu antara pre test dan post test.

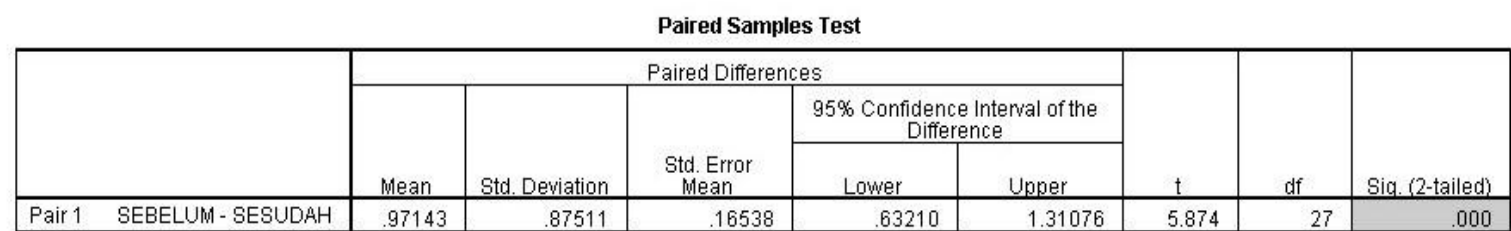


Ho ditolak dan Ha diterima karena sig $=0,000<0,05$, artinya selisih rata-rata berbeda sehingga dapat dikatakan treatment ladder drill efektif terhadap peningkatan hasil kelincahan.

Dari hasil penelitian didapatkan waktu kelincahan rata-rata hasil pretest adalah 16,73 detik, dengan waktu tertinggi 21,6 detik dan waktu terendah 14,6 detik. Sedangkan pada saat post test, didapatkan hasil waktu kelincahan rata-rata adalah 15,76 detik, waktu tertinggi 19,2 detik dan waktu terendah 14,2 detik. Dengan demikian terlihat bahwa ada peningkatan kecepatan dari pretest dan post test. Hal ini membuktikan bahwa treatment yang dilakukan mempunyai pengaruh positif terhadap hasil pretest dan post test.

\subsection{Pembahasan}

Ladder drill adalah latihan berbagai pola gerakan kaki yang berbeda. Melalui latihan tangga yang diletakan di tanah/lantai dimana seorang atlet di tuntut untuk melompat, bergerak ke kanan ke kiri secara cepat. Agility adalah kemampuan untuk meningkatkan, menurun dan cepat mengubah arah dengan pemeliharaan keseimbangan. Kecepatan dan agility ladder adalah salah satu yang terbaik peralatan pelatihan kelincahan yang membantu Olahragawan untuk belajar berbagai macam pola pergerakan yang berbeda. Tangga adalah alat multidirectional untuk meningkatkan gerak kaki dan bantuan untuk menggerakkan kaki cepat melalui pola yang kompleks, sehingga dari hasil penelitian yang dilakukan pada pemain UKM Sepakbola Unwahas dapat meningkatkan kemampuan kelincahan secara signifikan.

Dalam latihan ladder drill yang dilakukan selama penelitian, pemain dapat meningkatkan aspek keseimbangan, kecapatan, mobilitas dan koordinasi serta kecapatan reaksi yang mendukung peningkatan kemampuan kelincahan.

\section{KESIMPULAN}

Berdasarkan analisis hasil penelitian diperoleh hasil sebesar sig $=$ $0,000<0,05$, artinya selisih rata-rata berbeda sehingga dapat dikatakan treatment ladder drill efektif terhadap peningkatan hasil kelincahan, sehingga dapat disimpulkan bahwa ada pengaruh antara latihan ladder drill terhadap kemampuan kelincahan. 


\section{DAFTAR PUSTAKA}

Brown, Lee \& Ferrigno, Vance. 200). Training for Speed, Agility, And Quickness. United States: Human Kinetics.

Danny Mielke. 2007. Dasar-Dasar Sepakbola. Jakarta: Pakar Raya.

Djoko Pekik Irianto. 2002. Dasar Kepelatihan. Diktat. Yogyakarta: FIK UNY.

Djoko Pekik Irianto.Dkk. 2009. Materi

Pelatihan Kondisi Fisik Dasar. Jakarta: ASDEP Pengembangan Tenaga Dan Pembina Keolahragaan.

Sutrisno Hadi. 2004. Statistik 2. Yogyakarta: Andi Offset.

Ismaryati. 2006. Tes dan Pengukuran Olahraga. Surakarta: Sebelas Maret University Press.

Ngatman. 2010. Tes dan Pengukuran. Semarang: FIK UNNES.

Phil Devies. 2016. Ladder Agility Drills. http://www.sport-fitnessadvisor.com/ ladder-agilitydrills.html

Raynold, Tony. 2010. The Ultimate Agility Ladder Guide. www.PssAthletics.com

Schunemenin, Timo. 2012. Kurikulum Sepak Bola Indonesia. Jakarta: PSSI

Soewarno. 2010. Gerak Dasar dan Teknik Dasar Sepakbola. Semarang: FIK UNNES.

Sugiyono. 2010. Metode Penelitian Kuantitatif Kualitatif $R \quad \& \quad D$. Bandung: CV ALFABETA.

Sugiyono. 2015. Metode Penelitian Pendidikan. Bandung: Alfabeta.
Suharsimi Arikunto. 2005. Prosedur Penelitian Suatu pendekatan Praktek edisi Revisi IV. Jakarta: PT. Rineka Cipta.

Sukadiyanto. 2010. Pengantar Teori dan Metodologi Melatih Fisik. Semarang: FIK UNNES. 